\title{
THE MUSKINGUM WATERSHED CONSERVANCY DISTRICT: A STUDY OF LOCAL CONTROL
}

\author{
Lrie E. Craine* \\ I \\ INTRODUCTION
}

The creation of the TVA in r933 stands out as a landmark in the annals of drainage basin development. Less well-known is the fact that in the same year, the Muskingum Watershed Conservancy District (MWCD) was established to conduct a program of integrated land and water development in the Muskingum River basin of Ohio.

In addition to the coincidence of birth, the MWCD shares certain elements of paternity with the TVA. Both are a product of depression and New Deal public works programs; and both bear an early imprint of Arthur E. Morgan. The genetic relationship of the two agencies, in fact, extends to their fundamental purposes and objectives. The Muskingum District, in its infancy at least, viewed its mission as similar to that of the TVA and recognized that it, like the Authority, was a great experiment in the mobilization of the resources of a river valley for the benefit of its people. However, its founders were proud that the District was distinctive in its preservation of local responsibility and control. This was expressed by one of its early leaders when he said: ${ }^{1}$

The novelty of the Muskingum project lies in the fact that it is the first instance of cooperation between the United States Government and a local subdivision of a state government in such work.... If it works well, it will serve as a model for further cooperative effort between the national and local governments for flood control, water conservation, and social and economic improvement throughout the nation.

The Tennessee Authority is a federal corporation. The Muskingum Conservancy District is a state corporation. In the Tennessee Valley, the Federal Government takes the lead and invites cooperation from local subdivisions of government. In the Muskingum Valley, the Conservancy District takes the lead and receives cooperation from the Federal Government. But both projects develop a partnership or cooperative effort between federal and state governments for the conservation of natural resources and the general social and economic welfare of the nation.

* A.B. 1931, Oberlin College; Ph.M. 1937, University of Wisconsin; M.P.A. 1950, Syracuse University; Ph.D. 1956, University of Michigan. Associate Professor of Conservation, School of Natural Resources, University of Michigan. Director of research project on postwar government organization for natural resources and public works, United States Bureau of the Budget, 1945-47; Member and Assistant Director of the Program Staff, Office of the Secretary of the Interior, 1949-53.

${ }^{1}$ Address by Robert N. Wilkin, The Muskingum Watershed Project, delivered at the Annual Citizenship luncheon, Lakewood, Ohio, March 6, 1934. Judge Wilkin, a former member of the Ohio Supreme Court, was an early leader in the formation of the MWCD and scrved as its first general counsel. He is now a District Judge in Washington, D. C. 
Here, the MWCD recognized some relationship to the agency taking root in the Tennessee Valley, and as the "poor cousin" that it was, it laid down the challenge to its federal cousin.

However, the significance of a critical analysis of the Muskingum District in a symposium on water resources extends beyond the MWCD's common heritage with the TVA and such comparisons or contrasts as might be made. After more than twenty years of operating experience, many today believe that the District's unique contribution lies in the fact that "It demonstrated the great possibilities of watershed development and management for the public benefit ... [and] at the same time it showed how this could successfully be accomplished by local initiative, planning, organization and responsibility...."2 With the intensification of land and water problems of recent years, the need to practice integrated drainage basin development and watershed management has become increasingly urgent. There are many technical aspects of the interrelated behavior of natural processes in a drainage system which cry for further study and research. However, today the central problem in drainage basin development is less one of technical know-how than of social inventiveness in organizing people and their institutions for the coordinated administration of land and water development activities within the context of an appropriate drainage area.

The study and appraisal of various efforts in drainage basin development are fundamental to a better understanding of the requirements for effective administration of water resources programs. The MWCD is one such effort. It is the purpose of this paper to present a critical evaluation of that agency's experience in planning and carrying out a land and water development program in the Muskingum Valley.

There are many different facets of the MWCD's experience which are of significance to students of natural resources administration-whether they be interested primarily in law, economics, political science, administration, or various technical fields of resources management. This paper, however, must be limited to some of the broader aspects which relate more directly to organizing and administering a basin-wide program. Its objective, therefore, is to shed light on the following questions:

x. How effective has the MWCD been in developing and maintaining a comprehensive program of land and water development in the Muskingum basin?

2. How effective has the MWCD been in maintaining local direction and control of the development program?

3. What are the forces which have played upon the MWCD in its effort to maintain a comprehensive program and to retain local direction and control of the basin's development?

4. What do the MWCD's successes and failures suggest as to the role of a small agency for drainage basin development?

In considering the significance of the MWCD's experience as a guide for the

${ }^{3}$ E. H. Taylor, Senior Associate Editor of Country Gentleman, quoted in MWCD (1955). 
future, an important caution is noted. It should be recognized that the Muskingum basin is entirely within a single state. The MWCD's jurisdiction, therefore, is intrastate. This means that the MWCD has not had to cope with the complexities of interstate relations which often seem to constitute the major administrative problems in the larger interstate basins. Nevertheless, there are hundreds of intrastate drainages in this medium-size range which may find guidance from the Muskingum experience.

\section{II}

\section{The Muskingum Basin and Its Problems}

The Muskingum basin, located in southeastern Ohio, is the largest single drainage in the state. Containing 8,038 square miles, it comprises one-fifth the area of Ohio and geographically dominates the eastern half of the state. Extending approximately I25 miles north and south, the basin spreads 100 miles east and west at its widest points. The most northerly boundary of the watershed lies within twenty-five miles of Lake Erie, just west of Akron, and the southern boundary converges on the city of Marietta, where the Muskingum River discharges into the Ohio River. In 1950, one million of the state's six million people lived in the Muskingum Valley.

Physiographically, the basin is a part of the Allegheny plateau. Like most of this plateau, it is a highly dissected topography. Approximately one-third of the watershed in the northern and western portions has been levelled and filled by successive advances and retreats of the pleistocene glacier. In general, therefore, the topography changes from northwest to southeast from a moderately undulating glacial till plain of low and gentle relief, to sharp and intricate hill and valley topography of the unglaciated plateau, varying in altitudes from a low-water level of 570 feet at Marietta to 1,000 or $\mathrm{I}, \mathrm{I00}$ feet in the nearby vicinity.

The drainage system of the Muskingum basin is composed of the Muskingum River and four principal tributaries. The northeast quadrant of the basin is drained by the largest tributary, the Tuscarawas River, which rises in the western suburbs of Akron. The Wahonding River and its branches drain the northwest quadrant of the watershed. These two major tributaries join at Coshocton, the geographic center of the basin, to form the Muskingum River. Two lesser streams, the Licking River from the west and Wills Creek from the east, share the drainage of the southern portions of the basin with many smaller tributaries draining directly into the Muskingum River proper. Both the Licking and Wills Creek discharge into the main stem within thirty-five miles of the confluence of the two larger northern tributaries.

The Muskingum River from Zanesville southward is confined in a relatively narrow and deep postglacial valley. Thus, the Muskingum drainage area has many aspects of a true basin. From its outer fringe, a major part of its drainage converges on the general center of the basin, represented by a relatively short stretch of the 


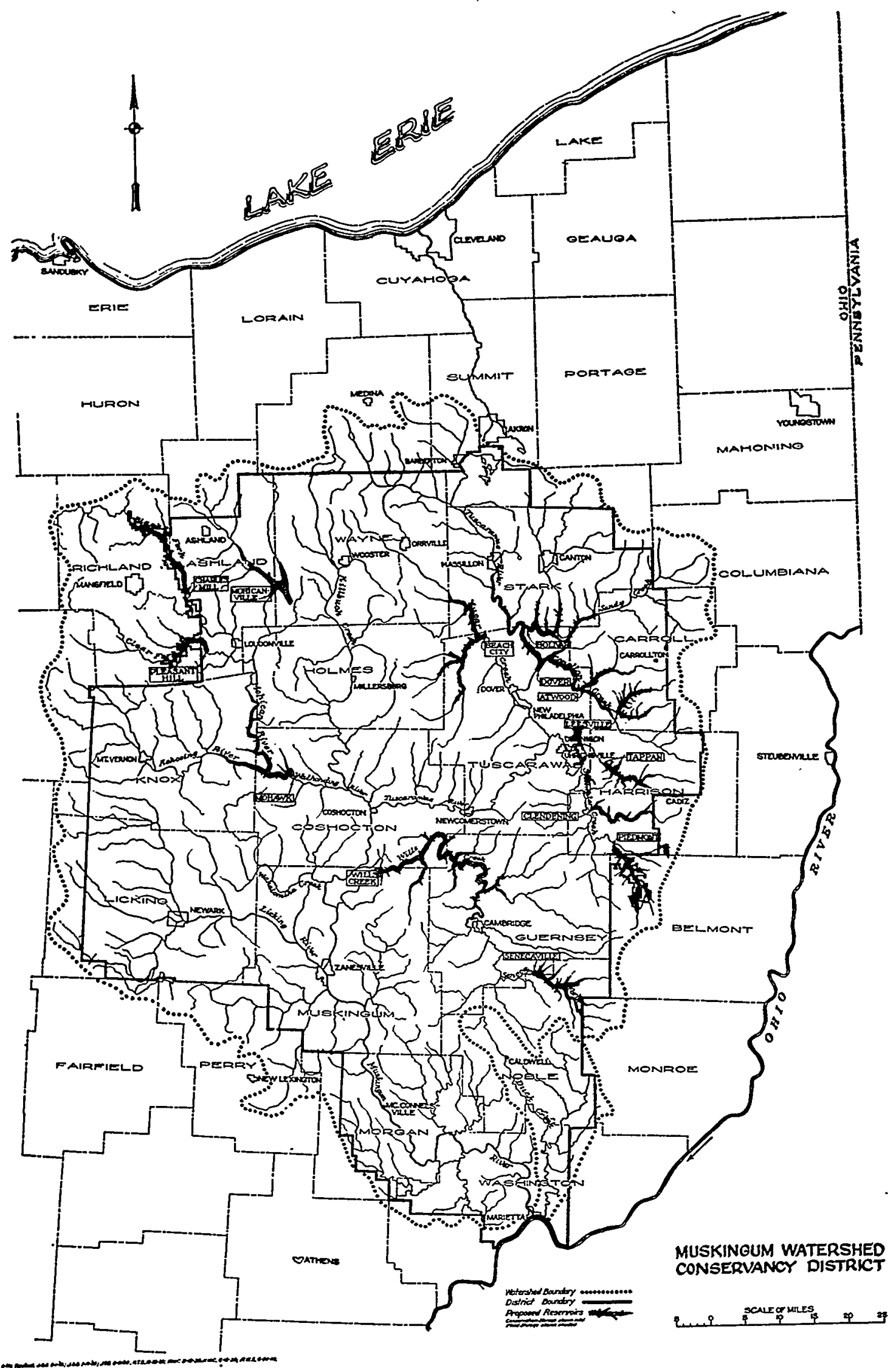


main stem. From this center, the drainage is bottlenecked through seventy-five miles or more of a narrow postglacial valley, to be discharged, as from the nozzle of a hose, into the Ohio River. Consequently, in times of excessive run-off, uncontrolled drainage, constricted at the outlet, backs up on Zanesville and Coshocton to produce extreme flood stages.

In many ways, the Muskingum Valley is the cradle of Ohio. The Ohio River was the great waterway to the West, and the Muskingum River was the gateway to the Ohio Territory. Early agriculture was confined to the bottom lands. But as the valley lands became thickly settled, newcomers were forced to stake out their claims in the adjoining uplands, which they soon discovered produced good crops. By $188 \mathrm{I}$, all but eighteen per cent of the original hardwood forest had been removed. By 1934, twelve per cent of the land still remained in trees. ${ }^{3}$

Changes from woodland to farm land during 125 years of settlement permitted accelerated run-off and rapid removal of the fertile top soil that produced good yields for the early settlers of the uplands. Especially on the steeper slopes of the unglaciated area, the removal of humus-charged absorptive topsoil has caused serious reduction in the water-holding capacity of the soil. It has been estimated that during the period of agricultural use, an average of five inches of topsoil-representing about one-half of the soil resources of the basin-have been removed from the farms of the watershed. ${ }^{4}$

By the r930's, erosion had made it imperative to convert a large proportion of the cropland to pasture. These pastures had a low carrying capacity. Many farms could no longer operate profitably. Abandoned farms, tax delinquency, state aid, and the number of families on relief increased. This situation hastened in the Muskingum watershed the changes which characterized much of the United States in the first decades of the twentieth century-the movement from farms to cities and villages and the movement from agriculture to expanding industries and commercial pursuits.

As the cities and villages along the watercourses grew, land and water problems intensified. The flood plains became more densely occupied; flood losses increased in frequency and magnitude; larger volumes of industrial and domestic waste were added to silt-loaded streams; pollution grew more serious; and water supplies became overtaxed.

These problems, arising from the manner in which the people of the Muskingum Valley used its land and water, were gradually emerging over the century of its human occupancy. Not until I933, however, did the forces for community action on the common problems of the basin congeal in the establishment of the Muskingum Watershed Conservancy District.

${ }^{3}$ See H. Howe Morse, Erosion and Related Land Use Conditions on the Muskingum Watershed (1939).

Id. at 2. 
III

\section{The Muskingum Watershed Conservancy District}

The MWCD and the Conservancy Act of Ohio, ${ }^{5}$ under which the district is established as a corporate subdivision of the state, had their roots in the great floods of I913 which wrought havoc and destruction on all of southern Ohio. The immediate impetus for the passage of the Conservancy Act came largely from the leaders in the Miami Valley. This valley, in which the city of Dayton is located, was the most severely damaged by the Igr3 flood. Soon after that catastrophe, the people of Dayton and of the Miami Valley organized to seek effective protection against recurring floods. As a part of their efforts, they sought state legislation which would enable counties to join together in special administrative and tax districts for the purpose of providing flood-protection measures. As a result of these efforts, the Conservancy Act of Ohio became law on February I7, Igr4. The Miami Conservancy District was the first of the Ohio conservancy districts organized pursuant to this enabling legislation. It was twenty years later before the Muskingum Valley utilized the authority of the Conservancy Act to establish the Muskingum Watershed Conservancy District.

The Conservancy Act authorizes conservancy districts for the purpose of preventing floods; regulating stream channels by changing, widening, and deepening the same; reclaiming or filling wet and overflowed lands; providing for irrigation where needed; regulating the flow of streams; and diverting or, in whole or in part, eliminating watercourses. Any area or areas in one or more counties may organize a conservancy district by filing with the clerk of the court of common pleas of one of the counties in the proposed district a petition signed either by 500 freeholders or by a majority of the freeholders in the territory to be organized. Upon determination of the sufficiency of the petition in accordance with law, the judge of the court of common pleas in which the petition is filed may decree the district established, and the conservancy court is organized.

The conservancy court consists of the judges of the court of common pleas of each county included in whole or in part within the proposed district. A presiding judge is elected from the membership of the conservancy court. Action of the court is by majority vote of the judges constituting its membership. In case of a tie vote, the side with which the presiding judge votes is considered the majority. The court may appoint three of its members to act as an executive committee in conducting hearings, and making determinations and findings, under rules established by the court. However, action of the full conservancy court is necessary in the establishment, dissolution, or modification of the district; the adoption, rejection, or amendment of the official plan; the appointment and removal of directors and appraisers; the confirmation of the appraiser's report of benefits, damages, and appraisals of property; the authorization of maintenance assessments in excess of

${ }^{5}$ Ohto Rev. Code Ann. c. 6ror (Page I954). 
one per cent of benefits; and the examination of the annual report of the board of directors.

A board of directors consisting of three persons, at least two of whom are resident freeholders, is appointed by the conservancy court for staggered terms of three years. The chairman of the board is elected from its members. The board of directors may employ a secretary, treasurer, chief engineer, and attorney, and such other staff as it deems necessary. The board of directors is responsible for directing the affairs of the district, subject to general policy direction and supervision of the conservancy court as described above. Specifically, the board of directors is responsible for preparing the official plan for the improvements for which the district was created; publishing and hearing objections to the official plan; adoption of the official plan; and recommending its adoption by the conservancy court. Provision is made for hearings before the conservancy court on any specific objections to the official plan as adopted by the board of directors. The board of directors is also responsible for constructing, maintaining, and operating all works or improvements necessary to complete, operate, and protect the official plan.

In carrying out these responsibilities, the board of directors is empowered to purchase or lease land and other property; exercise the dominant right of eminent domain over the rights of utility corporations; make and enforce rules and regulations primarily relating to the construction of bridges, sewers, roads, fences, etc.; contract with private individuals, private or public corporations, or the federal government for cooperation or assistance in constructing, maintaining, using, and operating the works of the district, or for making surveys and investigations or reports on the waters of the district; levy taxes and benefit-assessments; and issue bonds in anticipation of collections thereof.

It is important to note that the Conservancy Act originally was directed largely to the problem of flood control. Although irrigation "where needed" is listed among the general purposes, there is no reference to other beneficial uses, nor any recognition of land and water relationships in the watershed. Even with regard to irrigation, one section provides specifically that irrigation should in no way "... interfere with works for the prevention of floods, or the drainage of lands, or materially diminish their protective value." ${ }^{\prime 6}$ The principal intent of the original act was clear: to provide a public mechanism for controlling the excess water flow in stream channels. The MWCD was, however, to have a considerable influence upon broadening the purposes and authority of the Conservancy Act. These changes were made in 1937 .

For many years, particularly following the Igr 3 flood, small local groups in the Muskingum basin had attempted to organize for action on their local flood-control

\footnotetext{
Id., \$6ror.73.

"Many associated with the effort to obtain state enabling legislation for conservancy districts, even before the flood of 1913 , did not favor restricting the purposes of these districts to controlling excess stream flow. Had not the $\mathrm{IgI}_{3}$ floods thrown the leadership for such legislation to the flood-conscious Miami Valley group, the Conservancy Act might originally have been more broadly conceived.
} 
problems. Repeatedly, these individual efforts became dissipated. It was twenty years before the various localities and the various interests in the watershed became joined and the people of the region organized for a comprehensive approach to the basin's many interrelated problems.

The first systematic and sustained movement to organize the entire valley for flood protection had its roots in Zanesville in I927. In this year, the Chamber of Commerce of Zanesville engaged Bryce C. Browning ${ }^{8}$ as its manager and revitalized its flood-control committee. That this action, unlike many earlier ones, should be sustained and should conceive a program of comprehensive water resources management, was attributable to a fortunate combination of events and personalities.

One of the first acts of the new flood-control committee of the Zanesville Chamber of Commerce was to engage Dr. Arthur E. Morgan's firm, the Dayton Morgan Engineering Company, to conduct a survey and recommend a plan for flood protection for the city of Zanesville. That survey was significant for two conclusions: first, that it was not economically possible to provide any acceptable degree of protection for the city alone; and second, that the only way to obtain effective flood control at Zanesville was to design a control system for the entire Muskingum drainage above the city. Comprehensive control for the whole river system depended upon the understanding and participation of the people in the upper watershed. Efforts on the part of the Zanesville people to interest upland communities seemed futile. Why should they be interested in flood control for the downstream cities? But other movements were in the making to keep the cause alive.

In 1927, forces in Marietta also began to gain strength in a campaign for concerted action on the Muskingum flood problem. George Maxwell, associated with the Marietta flood-control committee, was to have considerable influence on selling the concept of comprehensive watershed management to the people of the valley. Maxwell, on the basis of years of experience in western water problems, became dedicated to the idea of "source-stream control." Not only was he active in selling land treatment and small structures as a vital part of any Muskingum program, but he also worked tirelessly to influence national water policies in this direction. By the spring of x930, Maxwell had joined forces with Bryce Browning in Zanesville, where he became executive director of a water and soil resources committee of the Zanesville Chamber of Commerce.

As though to set the stage for Maxwell's gospel in the upstream areas of the watershed, "Mother Nature," in the spring and summer of I930, visited upon the Muskingum basin one of the worst droughts in its history. The farmers and the small communities in the upper reaches of the watershed no longer thought the water problem was merely a problem of the downstream cities. The upstream cities experienced serious water shortages, the flow of the river was not sufficient to maintain sanitary conditions, and it became evident that future industrial development might

\footnotetext{
${ }^{8} \mathrm{Mr}$. Browning became one of the most influential leaders in the organization of the Muskingum program. He became the first Secretary-Treasurer of the MWCD, which position he still holds.

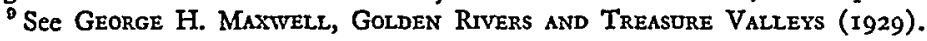


be limited unless steps were taken for water conservation. Mr. Maxwell was as much interested in water conservation as in flood control; to him they were inseparable parts of the same problem. Industries, villages, and cities then suffering from water shortages were eager to listen to Mr. Maxwell's proposals. As a result, there grew a realization of a "community of interest" between the upland areas and the river cities in water conservation and flood control.

Other forces for bringing the people of the valley together were coming into play about this time. Mr. Robert N. Wilkin, a practicing attorney in New Philadelphia, had been retained by a Dover steel company to investigate the possibility of making the Muskingum River navigable up to Dover and New Philadelphia, in order that the company might equalize its competitive position with other producers located on water transportation. Mr. Wilkin's investigation ultimately led him to Zanesville and to Bryce Browning. Another interest had thus been joined to the common cause.

The various emerging interests in the Muskingum development were called together in a meeting at New Philadelphia shortly after Maxwell joined the cause in the spring or early summer of I930. Some sponsors of the meeting were primarily interested in navigation, some in water power, some in reforestation, and some in soil and water control in the headwaters; however, flood-control interests dominated. At this meeting, the Muskingum-Tuscarawas Improvement Association was organized, which, in effect, federated the various local promotional organizations already created. Robert N. Wilkin was elected president, and Bryce Browning became executive secretary of this new promotional organization.

The first and perhaps the most significant action of the new association was to arrange for the Ohio Department of Public Works to finance ${ }^{10}$

... a reconnaissance survey and investigation of the Muskingum and Tuscarawas Rivers with reference to flood control, navigation, water supply, power development, sanitation, and other incidental uses pertaining to the control and use of the waters of these two streams....

The Department contracted with the Dayton Morgan Engineering Company to conduct the survey, the results of which were made available early in 1931. In general, the major significance of this second Morgan study was its finding that a comprehensive flood-control and water-conservation program for the entire drainage area was feasible but that it would probably cost over $\$ 50,000,000$, an expense greater than the watershed or the state could bear. It was further found that control of the Muskingum flood waters by such a system would have measurable effect in reducing flood crests and in improving navigation on the Ohio River, for which benefits there was a community of interest in other states and in the federal government.

Single-purpose development was declared by the report to be uneconomical, but it concluded that there was no substantial need for irrigation, that water-power

\footnotetext{
${ }^{10}$ Ohto Dep't of Public Works, Report on Water Resources of the Muskingum Drainage Area
} I (I03I). 
development was uneconomical "at this time," and that the proposal for navigation up to Dover seemed unwarranted. ${ }^{11}$ Stress was put upon flood control and water conservation, pointing out, in some detail, the rising demand for industrial and municipal water. Pollution abatement, reforestation, and soil-erosion control were also recommended.

In reviewing this second Morgan report, the Ohio Department of Public Works concluded that the state had considerable interest in the program proposed and should render substantial aid, but that it could not be the prime mover. In view of the large engineering enterprises being undertaken by the federal government at that time, the Morgan report had recommended that requests should be made for federal aid. However, no action was taken, and the whole Muskingum program was quiescent for nearly two years.

The progressive expansion of federal concern and responsiblity for flood control during this period had important influences on the evolution of the Muskingum program. Perhaps no less an influence, however, was the fact that before the organization of forces in the Muskingum had crystallized, the nation was thrown into the great depression. The New Deal program to combat unemployment rapidly changed traditional concepts of the relative roles of state and federal governments, and new opportunities for action appeared.

The Muskingum group was one of the first to present a request for federal aid to the Public Works Administration established by President Roosevelt in 1933 . Although the Muskingum representatives were given positive encouragement by PWA officials, they were advised that if the Muskingum project were approved, PWA would require some legally constituted local authority with which to contract for the execution and operation of the works. Plans were then accelerated for the establishment of a conservancy district under the Conservancy Act.

This was a critical point in the evolution of the Muskingum program. Two major issues arose. One was the extent of the financial liability which would be assumed by the people of the valley in creating a district; and the other, the question of how comprehensive the purposes of such a district should be. The judges before whom the petition for a district was heard were reluctant, in the face of a deepening depression, to take action which would saddle the locality with an additional tax burden. The decree establishing the Muskingum District was, therefore, made conditional upon obtaining federal financial assistance satisfactory to the conservancy court.

The second issue was raised by those who urged that the Muskingum District, in spite of dubious authority in the enabling act, should be conceived as a broad, comprehensive water resources management agency, and that the decree establishing it should state its purposes in the broadest terms, emphasizing beneficial uses of water

\footnotetext{
${ }^{11}$ Technological improvements in multiple-purpose engineering and changes in the economics of irrigation farming, energy, and transportation suggest the desirability of reviewing the feasibility of these scrvices in planning further development in the Muskingum basin.
} 
and collateral land-management measures. Others argued that the District should stick to the letter of the law and, like the Miami District, be restricted to water control. The latter, a small but vocal group, had the law on its side. But the former had the backing of reason and experience. When the decree was finally issued on June 3, I933, it established the District as a "watershed conservancy district" instead of just a conservancy district as is true of most other instrumentalities established under the Conservancy Act. Furthermore, the decree provided that the MWCD would have as its purposes not only the water-control functions itemized in the Act, but also the "conserving of flood waters for beneficial uses," and the District was authorized to carry on such additional activities as ". . f forestation, the building of check dams and other control works to prevent soil erosion and the consequent clogging of stream channels."

There is no doubt that the court order creating the MWCD conceived the District's purposes much more broadly than those authorized in the Ohio enabling legislation. In fact, the District's officials had some concern about the legality of its operations and worked diligently with a state committee to codify the Conservancy Act and to recommend amendments. The recodified law, with amendments, was adopted April 17 , 1937. These amendments, in general, authorize conservancy districts to include among their functions providing water for domestic, industrial, and water power purposes, pollution abatement, and the development of recreation facilities.

\section{IV}

A Conmprehensive Program or a River Control Project?

With its legal basis established, the MWCD set out to prepare a comprehensive development plan in keeping with the breadth of its basic charter. Relying essentially on the findings of the second Morgan report, the District prepared a preliminary plan which was submitted to the PWA with an application for financial assistance in August I933. This plan represented “. . . a coordinated and comprehensive program for flood control, conservation and development of water and other natural resources, river regulation, purification of streams, irrigation, prevention of soil erosion, and forestation." ${ }^{22}$ The program proposed was estimated to cost $\$ 53,640,000$. Of this, $\$ 42,925,000$ was for retarding basins and reservoirs. The District asserted that the plan could not be executed by the people of the District alone without the financial cooperation of the federal government. The MWCD, therefore, proposed that, ${ }^{13}$

due to the direct benefits to governmental functions; to the contribution by the project to flood control on the Ohio and Mississippi Rivers; to improved navigation; and to the federal government's general responsibility to assist in works for the conservation of natural resources, flood control, and the restoration of agriculture and industry, the federal government ... grant the additional funds required to complete the project.

12 MWCD, Statement of General Plan and Purpose 3 (1933).

${ }^{13}$ Id. at 7 . 
Unfortunately, the PWA was interested only in the large engineering and construction components of the plan, particularly those having to do with flood control and navigation. The action of the PWA upon the application, which was expressed in the contract of March 6, 1934 between the MWCD and the United States, had farreaching effects upon the character of the MWCD and its program. Three points regarding the provisions of this contract are significant to this study:

x. The PWA agreed to extend financial assistance on a project limited to the construction of some fourteen dams and reservoirs designed for flood control and water conservation. No part of its assistance could be used for land-improvement measures or for local flood-protection works.

2. Such a project was estimated to cost approximately $\$ 34,000,000$. The PWA agreed to provide $\$ 22,000,000$, while the District agreed to assume the costs of lands, easements, and relocations, as well as administrative and legal expenses, amounting to an estimated $\$ 12,000,000$. In addition, the District assumed the costs of operation and maintenance.

The state of Ohio subsequently agreed to provide one-half of the local share, through the provision of an estimated $\$ 4,000,000$ worth of highway relocations and $\$ 2,000,000$ in cash contribution to the cost of lands. This left the District with a total estimated liability of $\$ 6,000,000$, which it was to obtain through the special benefit assessment authorized by the Conservancy Act.

3. The PWA required that its grant to the project be administered by the Army Corps of Engineers and provided in the contract that the project should include fourteen reservoirs, the tentative location for each of which was given, or "such other reservoirs as may be agreed upon by the Conservancy District and the Corps of Engineers."

These provisions of the PWA contract were a major set-back to MWCD aspirations for a locally-directed comprehensive watershed program. The PWA's refusal to finance soil-conservation measures, forestation, and related works for source-stream control left these upstream features of the comprehensive program without financial assistance and started a general fragmentation of the comprehensive program. The PWA was adamant in its refusal to participate in these features and could only suggest that the District seek assistance in this phase of its program from other federal agencies. Likewise, by restricting assistance to only dams and reservoirs, even integrated planning of flood control was made difficult. Such local protection works as seemed desirable had to be financed by some means other than that provided in the project. However, since the dam and reservoir project had already committed the full financial capacity of the people, necessary local protection works had to be postponed to some uncertain future. The necessity to plan the reservoir system when the exact character and timing of the nonreservoir features were unknown compromised the achievement of a truly integrated flood-control scheme.

In many ways, the new role which was assigned to the Corps of Engineers in the 
Muskingum project may have compromised the aspirations of the MWCD as much as the limitations attached to the grant. What was the justification for injecting another federal agency into the project? Some contend that it was a bone tossed to the Army Engineers after they had been deposed from the Tennessee River by President Roosevelt's promotion of the TVA. However, PWA officials insisted that the Corps of Engineers' participation was necessary because the grant was large relative to others being made to local units of government and because a large share of the flood-control benefits was to accrue on the Ohio River, outside the jurisdiction of the MWCD.

Both factors may well have influenced the decision. Under the circumstances of its denial of a part in the Tennessee development, it is entirely possible the Corps's participation in the Muskingum was a quid pro quo. However, the PWA's justification for the Army engineers supervising the Muskingum project is of even greater significance to this study. Here we see an expression of the pressures of political realities in a development program of this kind. Where benefits extend beyond the jurisdiction of the local agency and where costs are borne by a higher level of government, the broader jurisdiction demands a share in the responsibility for the development.

The Muskingum River control system, authorized by the "Project and Official Plan" agreed upon between the District and the Corps of Engineers, consists of fourteen reservoirs, ten of which maintain a permanent water pool. The river control system is designed, in so far as practicable, to provide an effective distribution of both flood-control and water-conservation features throughout the basin. It provides $1,327,800$ acre-feet of flood-control storage and 211,400 acre-feet of waterconservation storage, so located as to control over 62.4 per cent of the basin above Zanesville and 70.7 per cent of the basin above Coshocton. The system as a whole contains flood-control storage thirty-six per cent greater than would have been required in the I9I3 flood, and thirteen per cent greater than would have been required had the I9I3 storm been centered over the Muskingum basin. The ten permanent conservation pools provide 16,380 surface acres of water in a section of Ohio plagued by a dearth of natural lakes. These reservoirs are operated to maintain minimum flows equal to the mean flows that existed prior to their construction.

Clearly, the Muskingum River control project, made possible by the PWA grant, fell far short of the comprehensive program for land and water management which the MWCD had envisioned. New patterns of federal, state, and district relations were developed in an effort to provide the related land-water conservation aspects of the original comprehensive plan. At the same time, adjustments in financial relations between the federal government, the state, and the District were necessary during the course of project construction. These changes in intergovernmental relations induced significant shifts in the role of the MWCD as a drainage basin development agency. The remaining parts of this paper are devoted to a descriptive 
analysis of these changes and their impact upon the MWCD as a local agency of drainage basin development.

\section{$\mathrm{V}$}

\section{Financing the River Control Project}

Plans for financing the Muskingum River control system required many changes throughout the course of construction, particularly during the four-year period from the final approval of the "Project and Official Plan" in I935 to the passage of the federal Flood Control Act of $1939 .^{14}$ Basically, shifts in the financing arrangements for the project resulted from complex interactions between two fundamental factors: first, the natural reluctance of the people of the valley to assume additional tax burdens in the deepening depression; and second, shifting federal policies relating to the role of the national government in all phases of natural resources management generally, and in flood-control projects in particular.

Financial problems arose almost before final approval of the "Project and Official Plan." It became evident that both construction and land acquisition costs would be higher than estimated. This seriously upset the budgets both of the Corps of Engineers, which was responsible for construction, and of the District, which was responsible for purchasing the necessary land, flowage easements, and rights-of-way.

In March 1936, approximately one year after approval of the "Project and Official Plan," the Corps was granted an additional $\$ 3,500,000$ for construction purposes. A major part of the justification for this additional grant was based upon the increased construction costs owing to the changes in plans for meeting the local flood situation at Massillon." ${ }^{15}$ How much was attributable to this change in the "Project and Official Plan" and how much to original underestimates is not a matter of record.

Financial relief for the District presented greater problems. Under the original plan for financing, the MWCD had assumed the cost of land acquisition, administration, and legal services to the extent of $\$ 6,000,000$. In March 1937 , with about onehalf of the land acquisition completed, the District estimated that the cost of lands, easements, and rights-of-way alone would amount to over $\$ 6,000,000$. Relief from the rising obligation of the District became imperative.

On June 27 , 1937, the MWCD was awarded an additional grant of $\$ 1,600,000$ from the PWA to reimburse the District for increased cost of lands. In return, the MWCD transferred to the United States title to the lands necessary for the dams. The District's justification for federal assistance in land acquisition was based upon the claim that land costs were higher than expected because: (I) the relocation of certain dams by the Corps of Engineers in order to increase federal benefits in the Ohio Valley had involved higher-value lands; and (2) the emphasis upon acceleration of the work in order to relieve unemployment had resulted in construction starting

${ }^{14} 53$ STAT. 14 44,33 U. S. C. $\$ 7$ TOI (I952).

${ }^{15}$ Although the original PWA contract prohibited the inclusion of local protection works as a part of the project, an amendment to the contract was negotiated to include the Massillon project as a special case. 
before land purchase negotiations were initiated. Furthermore, the District contended that because relief measures and employment opportunities on the project had not resulted in the economic relief anticipated, property owners were still without adequate means to pay their assessments.

Changes in federal policy, particularly regarding the national government's role in flood control, had far-reaching impact upon the Muskingum situation. The Flood Control Act of 1936 had accepted a federal responsibility to provide flood protection where benefits, to whomsoever they may accrue, exceed costs. ${ }^{16}$ Local interests were required to provide lands, easements, and rights-of-way, just as was required by the Muskingum contract. However, unlike the Muskingum contract, the act did not require local interests to assume the costs of operating and maintaining the dams and reservoirs. And in the 1937 amendments to the Flood Control Act, the President was empowered to waive, up to fifty per cent, even the requirements for local participation in land acquisition if the locality were unable to pay "by reason of its financial condition." 17 It is not surprising, therefore, that the Muskingum people increasingly compared these national developments with "their deal," and as federal policy provided more favorable terms for the same services elsewhere, voices in the Muskingum were raised in support of any effort to receive equally favorable treatment.

In spite of its additional grant in 1937 , the MWCD in early 1938 estimated its remaining obligations to be approximately $\$ 7,000,000$, to be paid in large part by the owners of approximately 24,000 properties who would receive flood-control benefits. On the basis of benefits appraised, the board of directors levied a fifty per cent assessment, amounting to $\$ 5,800,000$. The Conservancy Act authorized the issuance of bonds against ninety per cent of the unappealed assessments. With unappealed assessments of $\$ 4,247,000$, the board of directors, on May I, I938, therefore, authorized the issuance of bonds in the amount of $\$ 3,822,000$ against anticipated assessment collections. This action established the basis for the financial operations of the District.

With the announcement of the first semiannual assessment collection early in 1938, protests of property owners to assessment levies mounted. In most areas, protest movements soon dwindled and the assessment installment was paid. In the city of Newcomerstown, however, protests reached crisis proportions. Here, certain interests felt that benefit assessments fell with disproportionate severity upon their properties. Fired by the local press and supported by one of Ohio's senators, this protest movement turned into a local "tax-strike," since, by law, these assessments were made an integral part of the property tax. A large portion of Newcomerstown taxpayers were in default, and the schools and city services were threatened with insufficient funds on which to operate. Local opinion began to develop that the federal government would be willing to take over and run the project if the District

\footnotetext{
${ }^{16} 49$ STAT. 1570,33 U. S. C. \$701a (1952).

1750 Stat. 877 .
} 
would dissolve. The issue came to a head when the residents of Newcomerstown passed a resolution reminiscent of early colonial days, saying: $:^{18}$

$\mathrm{Be}$ it resolved by the citizens and taxpayers of the Village of Newcomerstown in Convention Assembled: That we tender payment of our taxes and assessments exclusive of the said Muskingum Watershed Conservancy District taxes and assessments, and, if the same be refused by the tax collecting authorities, then and in such event, we declare our intent, as did our forefathers when unjustly taxed by the Tyrannical King George III of England, to pay no tax assessments until such time as we may be relieved of the unbearable burden of such watershed assessments.

$\mathrm{Be}$ it further resolved, That we believe that the only just and possible solution of the present condition is for such Conservancy District to be deeded in its entirety to the United States Government to be by it paid for and operated under the general Flood Control Laws of the Country; to be under the complete control of such government as its sole expense for construction and operation.

Efforts were made to enjoin the benefit assessment collection in order that "legitimate taxes" could be paid. Legal battles ensued, and on October II, r939, the court approved the MWCD's request for dismissal of an order restraining collection of the District's assessments. The MWCD had won its legal right to collect the assessments levied. However, in spite of the remarkably good assessment collections elsewhere in the District ${ }^{10}$ and in spite of the evidence that the Newcomerstown "tax strike" was a locally exaggerated situation, it seems clear that the Newcomerstown protest reflected a significant attitude throughout the basin with which the MWCD was forced to reckon.

This question the District could not escape: Why should the people of the Muskingum Valley contribute more to their flood-control protection than was now required of other areas which had shown no initiative in facing up to their flood problems? Subsequent events indicate that the need to obtain further relief from its financial commitments dominated the future efforts of the MWCD.

The Flood Control Act of $193^{20}$ affected the Muskingum significantly. This act further liberalized federal flood-control policy by providing, in effect, that local units of government were relieved of all responsibility for acquiring lands, easements, and rights-of-way and for operating and maintaining those projects authorized in the I938 act or previously authorized by the Flood Control Acts of 1936 and r937. In addition, section four of the 1938 act was significant to the Muskingum project in two specific respects: ( $I$ ) it authorized and directed the Secretary of War to reimburse the MWCD, not to exceed actual expenditures made by the MWCD for acquiring lands, easements, and rights-of-way, and not to exceed $\$ 4,500,000$; and, (2) in authorizing additional works in the Ohio basin, it included seven new projects for the Muskingum, three of which were additional reservoirs, and four of which

${ }^{18}$ Newcomerstown News, Dec. 15, 1938, p. I.

10 Of the 24,000 properties on which assessments were levied, appeals to appraisals were received on about $20 \%$ of the properties, amounting to about $27 \%$ of the appraised value. By the time the first semiannual levy became due in December 1938 , only 887 appeals remained outstanding.

${ }^{20} 52$ STAT. I215, 33 U. S. C. $\$ \$ 701,702,706$ (1952). 
were local protection works, originally prohibited from the basin project by the terms of the PWA grant.

Since the Muskingum project was not specifically authorized by Congress in the Flood Control Acts of 1936 or 1937, the general policy changes regarding local financing contained in the 1938 act did not fully apply to the original Muskingum project, and the people of the valley, again, did not share equally in the favors of the federal government. For, while section four of the 1938 act provided specific reimbursement to the MWCD for the cost of lands, easements, and rights-of-way, ${ }^{21}$ it did not cover the administrative costs of acquisition, nor did it relieve the District of the responsibility for maintaining and operating the project.

In spite of the considerable relief promised the Muskingum District by the reimbursement authorized by the 1938 act, it was clear that the Muskingum Valley was still not as favored by the federal government as those areas which had waited for the Congress to bring them free flood protection. This fact continued to fire the objectors to the MWCD assessments and induced the district officials to a policy of avoiding further assessment collections if possible.

The question of how much the Muskingum project should continue to be a responsibility of the Muskingum people dominated MWCD policy deliberations and public controversy in the region through 1938 and early 1939. Receipt by the District of the reimbursements authorized by the Flood Control Act of r938 would have relieved the MWCD of the immediate necessity to collect further benefit assessments in order to meet bond service requirements. However, the Corps of Engineers appeared to be delaying the reimbursements provided by law, and the need for further assessment collections threatened. Such threats sharpened local protests and made local opinion more amenable to further federal control. Perhaps the delay by the Corps of Engineers in making reimbursement payments was related to the Corps's hopes that time would demonstrate the desirability of it taking over the entire flood-control operation of the Muskingum project. Preliminary discussions were held regarding the kind of transfer arrangements that might be worked out between the District and the Corps. The MWCD's board of directors was split two to one in favor of cooperating in the transfer of its flood-control project to the Corps of Engineers. ${ }^{22}$

This was a critical juncture in the development of the MWCD and its program of drainage basin development. If the Corps of Engineers took over the entire project for flood control, how could the other purposes for which the project was originally conceived still be achieved? The Corps had authority for flood control but no authority relating to beneficial uses of the conservation storage nor authority for forestation or recreation. On the other hand, sentiment was strong to make such

${ }^{21}$ MWCD, Summary Statement for Lands, Easements, and Rights-of-Way as of March i1, i937 (1937) estimated the total cost of these items at $\$ 6,253,000$. The grant of $\$ 1,600,000$ would have reduced the MWCD investment to about $\$ 4,600,000$. It would appear, therefore, that the $\$ 4,500,000$ reimbursement authorized in the 1938 act was intended to be full reimbursement for land costs.

${ }^{22}$ Letter from Bryce Browning to the author, June 21, 1955. 
arrangements as were necessary to obtain for the Muskingum the full benefits of federal flood-control policy. It appears that the flood-control purposes of the Muskingum project had become so dominant in the minds of the residents, and even the board of directors, that the dilemma with which they were confronted seemed not particularly significant. Dams and reservoirs meant flood control; these they had; if they could sell them to the Corps at cost, the valley would gain flood control at the minimal cost of the first semiannual installment of benefit assessments. This seemed like a deal too good to turn down. Negotiations were under way in Washington to obtain a provision in the then pending Flood Control Act of 1939 to transfer the entire flood-control operations of the Muskingum project to the Corps of Engineers. Events were moving fast. A few leaders, however, maintained their vision of the broader purposes and benefits of the potential developments in the valley, and continued to resist a complete capitulation.

On August Ir, I939, the Flood Control Act of r939 became law. As finally passed, section four of the act provided the following with respect to the Muskingum project:

I. The Muskingum River dams and reservoirs were included as part of the floodcontrol plan for the Ohio River basin authorized by the Flood Control Act of 1938, and, thereby, the Muskingum project qualified under the general policy of the Flood Control Act of 1938 , which eliminated all requirements for local financial participation.

2. Reimbursements to the MWCD were authorized to include, in addition to payments made to landowners for the acquisition of lands, easements, and rights-ofway, as authorized in the $193^{8}$ act, the reasonable expenses of acquiring lands, easements, and rights-of-way heretofore transferred to the United States. All reimbursements were to be made for those expenditures "deemed reasonable" by the Secretary of War and the Chief of Engineers.

3. The Secretary of War was authorized to pay "forthwith on the passage of the Act" the sum of $\$ 1,500,000$ on verification that reimbursable expenditures of that amount had been made by the MWCD and on agreement by the District that it would proceed immediately to transfer any assets acquired through such expenditures.

4. The MWCD was ". . . relieved of any obligation to maintain and operate the dams."

Clearly, the Flood Control Act of I939 transferred the entire flood-control operation of the Muskingum project to the Corps of Engineers. The people of the Muskingum Valley had obtained the same advantages from the federal flood-control policies as were available to the people of any other valley. It appeared, moreover, that the intent of the Newcomerstown Resolution had been realized-namely, to deed the District ". . . in its entirety to the United States Government to be by it paid for and operated under the general Flood Control laws of the Country. . .."23

However, the I939 act left the MWCD with two major problems: first, clarifying its position regarding its title to the reservoir properties; and, second, negotiating a ${ }^{23}$ Suprat note 18. 
definitive financial settlement with the Corps of Engineers, including the amount, timing, and manner of reimbursement authorized by the Flood Control Acts of 1938 and 1939. Both of these problems became major ones as a result of the ambiguities of the 1939 act. Both had been raised during the drafting of that act, and the clarification of each had been left for future negotiation. Had the various groups within the Muskingum been of greater singleness of mind and purpose regarding the transfer to the Corps of Engineers, many of these ambiguities probably could have been avoided.

The question of the extent to which the MWCD could legally divest itself of title to reservoir lands had been argued in Washington. With the passage of the act, the question was directed to the Ohio Attorney General who returned his opinion on February 6, 1940. ${ }^{24}$ In it, he concluded that the District did not have the authority to dispose of all its lands in fee simple. The opinion pointed out that if the District were to transfer all its land to the federal government, the District ${ }^{25}$

... would then be without purpose; it would not have the facilities with which to carry out its other purposes of water conservation, soil erosion prevention, forestation, the development of recreational facilities thereon, as contemplated in its adopted plan. Its possible function would necessarily cease except for the collection of funds through assessment and otherwise for the payment of its bonds.

The Attorney General made it clear, however, that he did not rule against agreements with the federal government by which it might construct and maintain flood-control projects, nor against conveying to the United States an interest in the property of the MWCD for flood-control purposes. The legality of either action would depend upon the District retaining such property rights as are "... necessary for it to exercise and complete its purposes other than that performed by the Federal Government." ${ }^{\prime 2}$ This led the way to a final agreement with the Corps of Engineers by which the MWCD assigned to the federal government flowage easements over those district lands required for flood-control operations, while the District maintained title and control to the reservoir properties for all purposes other than flood control. Consequently, since that time, the MWCD's activities have increasedly concentrated on problems of reservoir properties management.

The reimbursement problem arising from the Flood Control Act of 1939 has, in many ways, been a malignancy to the District. With the passage of the act, the people in the valley generally believed that they were assured of no further assessment collections. Yet, the timing and quantity of reimbursement payments were at the discretion of the Corps of Engineers. Under such circumstances, the MWCD was never able to develop any systematic plan for meeting its bond obligations. Delays in reimbursement payments frequently threatened the MWCD with the necessity of collecting additional assessment levies, but at the last minute, the Corps would come through, just in time to save the District such public embarrassment. As a result,

\footnotetext{
24 I OPs. ATT'Y GEN. OHO 123 (I940). ${ }^{25} 7 d$. at 13r.

${ }^{20} I d$. at 132 .
} 
the MWCD has been kept "over the barrel" for many years. Not until October 1955, when a final settlement consummated fifteen years of negotiation, was the spectre of another assessment collection finally removed from the MWCD's operations. This settlement now assures the District that it will be able to liquidate its bonds when they became callable in 1958 , without further assessment collections. This means that the first semiannual levy which was collected in $x 93^{8}$ essentially constitutes the total local financial contribution to the dam and reservoir system. This contribution amounts to about $\$ 800,000$ out of the total project cost which probably exceeded $\$ 50,000,000$.

The four years from time of final approval of the "Project and Official Plan". to the passage of the Flood Control Act of I939 spawned several actions that had farreaching effects upon the MWCD. First, it is clear that these events resulted in the federal government, and to a lesser extent the state, assuming an increased proportion -almost to the point of roo per cent-of the project costs. The action in I939 removed almost the last pretense of local participation, at least in the flood-control aspects.

A second product of shifting financial arrangements was the somewhat uncertain status regarding the District's and the state's investment in the water-conservation features of the project. By virtue of the opinion of the state's Attorney General, the District retains title to some 65,000 acres of land and water which constitute the reservoir properties. The MWCD conducts activities involving the development of these properties for forestry and recreation and their leasing for farming and minerals exploitation. These programs are claimed to be self-supporting; yet, in their operations, no charges are made to amortization of the capital investment in the reservoirs themselves. Does the contribution of $\$ 800,000$ by the District plus perhaps $\$ 6,000,000$ to $\$ 8,000,000$ contribution by the state represent an adequate share in the costs of the capital facilities? Probably this question can never satisfactorily be answered without a cost allocation analysis of the existing reservoirs to serve as the basis for determining the share of total costs assignable to flood control and to water conservation.

Third, the events of this period, particularly the obvious protests against assessments, forced the MWCD, in initiating its reservoir-management activities, to assure the people of the valley that these functions could be "self-supporting." Recreation services, forest-management actions, and other services from the water-conservation pools which do not offer a break-even possibility have been less attractive and often disregarded in the MWCD reservoir property management.

VI

\section{The MWCD's Changing Role}

There is little doubt that the Muskingum program, as originally conceived in the preliminary plan presented to the PWA in 1933, was unique for its day. It was unique both in terms of its comprehensiveness and in terms of the character and extent of local participation it assumed. Today, however, it is obvious that the 
MWCD has had to compromise the integrity of the unified comprehensive plan which it conceived, as well as its role in drainage basin development in the Muskingum. These compromises were induced by the interwoven chain of events and circumstances with which the District was confronted in the two decades or more of its existence. The most significant of these have been described and analyzed above. Through this progression of compromises, the MWCD has played several distinct roles with regard to the development and management of the land and water resources in the Muskingum basin.

At first, the District assumed that it would perform as an independent local agency in the administration of its proposed comprehensive development program for the basin. Even though it sought federal financial assistance, it seems clear that it presumed a free hand in its administration, subject to PWA approval of policies and plans. It was with real consternation that the MWCD officials, on the last day before contract approval with the PWA, learned that the Corps of Engineers was to be responsible for the administration of the federal grant. ${ }^{27}$ From the very first, then, the District's independence was violated. From the perspective of 1957, it may appear that the MWCD's assumptions in this regard were somewhat naive. Sound policy and administration may always require a degree of federal participation wherever federal appropriations are utilized. In this case, where the MWCD justified federal participation on the basis of flood-control benefits extending to the Ohio River, a case certainly existed for the Corps to be assigned technical supervision. Following contract approval, the District's independence progressively diminished with the successive changes in financial arrangements which finally culminated in the provisions of the Flood Control Act of 1939 and the administrative negotiations involved in obtaining reimbursements authorized therein.

The PWA action upon the District's application for financial assistance not only violated the MWCD's independence, but, by approving only the river control system, the PWA, in effect, broke up the District's comprehensive watershed plan. This forced the MWCD to take a fragmentary approach to achieving the land-water aspects of its comprehensive plan and led the District into a second type of role-that of a local, unofficial coordinating agency. By 1938 , this role was being emphasized by the District. ${ }^{28}$

Eager to get erosion-control and reforestation work started throughout the watershed, the MWCD's efforts were directed to the development of cooperative programs with various federal agencies which could help in these and related activities. The Works Progress Administration (WPA), the Civilian Conservation Corps (CCC), and the National Youth Administration (NYA), as well as the newly created Soil Erosion Service (later the Soil Conservation Service) and such established agencies as the National Park Service and Forest Service all contributed immeasurably to advancing various phases of land and water management in the Muskingum basın.

${ }^{27}$ Interview with Judge Robert N. Wilkin, Washington, D. C., Dec. 9, 1954.

${ }^{28}$ See MWCD, Working Together in the Muskingim Valiey 26 (n.d., but reported to have been published in 1938 or 1939 ). 
The extent and nature of the participation of various federal agencies under their several emergency authorities were influenced in large measure by the MWCD. Petitioning for projects, suggesting locations of need, aiding in establishing necessary local arrangements, offering small financial contributions to cost, arranging local gifts of land, and assuring permanent operation and maintenance were all devices used in one situation or another to attract to the Muskingum Valley what has generally been recognized as a greater than its proportionate share of federal emergency projects dealing with land and water management.

In this kind of operation, the MWCD played an increasingly significant coordinating role, in which its effectiveness stemmed from three features which it then possessed.

First, the MWCD held a position of leadership among the people of the basin with respect to their watershed problems which it had inherited as a product of the predistrict programs of public education in watershed problems, potentialities, and needs. The work of Browning and Maxwell in Zanesville and later the work of the Muskingum-Tuscarawas Improvement Association had developed a "community consciousness" within the basin, the leadership for which was passed on to the MWCD when it was established in I933. This devolved upon the District the authority and power of enlightened community interest and made the MWCD the administrative focus with respect to watershed problems. This kind of "authority," when properly utilized, is not lightly dismissed by state or federal agencies.

A second feature which strengthened the District as a coordinator was the fact that it had a comprehensive plan for the management of the land and water resources of the basin which was locally developed and supported. Although this original "general plan" was never officially approved, it had wide public support throughout the basin. Moreover, it provided a framework within which the District could request further assistance from the various agencies and from which each agency could see its contribution to the over-all basin's objectives.

More specifically, the legal status of the "Project and Official Plan" for the river control system has given the MWCD a powerful implement of coordination. The official plan has been effective both with the Corps of Engineers, regarding reservoir operations, and with other agencies whose programs relate to the management of reservoir properties. There have been occasions when the Corps has sought to operate the Muskingum reservoirs so as to change stream flow or to provide a greater degree of flood control on the Ohio than that provided by the plan. When these operations have threatened to change reservoir levels from those provided in the plan, thus jeopardizing other benefits, the District has been able to cite the Corps as being in violation of contracts of which the maintenance of reservoir levels, as provided for in the "Project and Official Plan" is a part. Likewise, contractual agreements with the Ohio Division of Wildlife for the fish and game management on the reservoir properties include provisions protecting the integrity of the MWCD's official plan. These have served effectively in keeping the work of this state agency 
coordinated with the over-all program for the management of the reservoir properties.

A final and fundamental factor in the MWCD's effectiveness as a coordinator was its ability to raise local funds in support of the drainage basin development program. Without the ability to assume even the limited financial obligations which it did, it would have had little participation in the "Project and Official Plan." Furthermore, there are indications that many of the ancillary land-development programs were induced in the Muskingum area rather than elsewhere because of the District's ability and willingness to contribute land or cash. Even a small amount of local financial participation apparently bought a lot of "say" in how state and federal agencies conducted their programs in the area.

That the MWCD once played an effective role as coordinator based upon these three essential features of its situation is an important point in this study. Of equal significance, however, are (I) the fact that it gradually has lost its coordinating role, and (2) the factors which contributed to this deterioration in its position.

As the Muskingum people reneged on their financial participation, the District's effectiveness in basin-wide problems diminished. Forced to fight a rearguard action on financial matters, the MWCD's efforts were dissipated. The job of analyzing the basin's land and water problems, following the progress in their solution, and pointing the way to better action, got little attention from the MWCD. Its failure to keep up on basin-wide problems led to its loss of leadership in the watershed community and weakened the District's voice among agencies.

It seems clear that the immediate aftermath of the Flood Control Act of 9939 left the MWCD with a new but greatly limited role. It no longer possessed a favorable posture for effective coordination. Instead, it now retreated to the position of manager of the reservoir properties. The forces which had already been at play in vitiating the District's broader role continued, and new ones were added. Federal and state governments took on expanded responsibilities regarding land and water, with little attention tc their impact upon a local watershed agency. Two cases may be described here as examples. Emergency soil-erosion-control work became a permanent federal program under Soil Conservation Service, to be administered through local soil conservation districts. Although the MWCD extended its full effort in support of Ohio enabling legislation and in encouraging the establishment of districts in the Muskingum drainage, today the MWCD, as an agency, knows little of the progress or problems of soil conservation throughout the watershed. It would appear that the administrative organization under which Soil Conservation Service operates discourages the MWCD from maintaining a watershed orientation with regard to soil conservation. For example, soil-conservation districts are set up on a county basis, without regard to subdrainages within the valley; and the SCS administrative supervision of the work in the basin is divided between two area conservationists, each of whose areas includes parts of other basins. A second example of the impact of federal and state expansions on the MWCD is found in the case 
of water pollution. Here, the assumption by both Ohio and the federal government of pollution-control responsibilities and the creation of the Ohio River Sanitation Commission has permitted the MWCD to withdraw also from pollution matters in deference to higher levels of government.

But a factor of greater force in narrowing the MWCD's role to that of reservoir property manager was internal rather than external. Those same forces which urged the MWCD to turn flood control over to the Corps of Engineers urged the MWCD's board of directors to adopt an unwritten policy of "self-support" with regard to the District's reservoir property management. Today the District boasts of being selfsupporting. Too often this claim is not understood for what it is-namely, that the District's operation of forestry, recreation, and farm and mineral leasing on the 65,000 acres to which it still holds title returns sufficient revenue to meet current operating expenses plus servicing recreation bonds which were sold to finance capital improvements required for recreation developments. Such a claim gives no consideration to a proper cost allocation with respect to the $\$ 50,000,000$ investment in the dams and reservoirs and an appropriate amortization charge with respect thereto. This "self-support" policy, moreover, has removed from the MWCD practically all concepts of a public service agency, except as its services can pay their way from collectible revenues.

The "self-support" policy has, in effect, given to the MWCD many of the colorations of a private rather than a public enterprise. Recreation services and forestry activities which have little prospect of being self-supporting are given scant attention. Although as a public corporation, the MWCD is exempt from property tax, the District insists upon paying tax to the local subdivisions of government in which its properties are located, without regard to the benefits derived by the local subdivisions from the District's operation. Similarly, the District has taken the position that; in order to avoid the criticism of subsidy, it should continue to purchase its tree seedlings for reforestation, even if planting stock were made available free of charge from other public agencies.

Nevertheless, the MWCD's programs in forestry and recreation on its reservoir properties are, without doubt, outstanding examples of multiple-purpose conservation management. Its accomplishments in these programs fully justify its reputation as an "impressive demonstration of what can be accomplished by local conservation initiative, leadership and cooperation." ${ }^{20}$ "However, it is important to distingursh these reservoir-management activities from a vital basin-wide program of land and water development.

\section{VII}

The Future of the Small Drainage Basin Development Agency

In spite of the MWCD's failure to maintain itself as an independent local agency for drainage basin development, it did play a significant role in the Muskingum de-

${ }^{20}$ Butler, The People Take Over in Muskingum Valley, American Forests, July 1949, p. 48. 
velopment. Its experience in the various roles it has played suggests the contribution which an agency of this kind can make in the complex environment of federal, state, and local governmental relations which characterize drainage basin development and watershed management today.

It is clear that programs even of the size of the Muskingum's involve both geographic and governmental jurisdictions which are larger than that of a local drainage basin agency, such as the MWCD. For one thing, any significant development in an area of this size involves works the costs of which usually exceed the financial capacity of the locality. Moreover, where benefits extend beyond the basin, as they inevitably do, some larger jurisdiction is appropriately involved. In the case of the MWCD, this might have been a federal or interstate Ohio Valley Authority; but lacking that, functional agencies of the federal government became involved. Inescapably, a larger jurisdiction which is able to identify sufficient benefits in local developments to justify its financial participation must ultimately also share the decisions in some proportion to its share of costs. Thus, a program of the scope of the MWCD's cannot be independently planned and executed by a local agency.

Moreover, not only is local independence impossible, it is undesirable. In fact, independent operation by any level of government in drainage basin development is undesirable. Total and comprehensive drainage basin development will always demand the full contribution of each level of government. This suggests that the problem is not so much one of demarcating functions or areas within which each governmental agency can operate relatively independently, but rather one of devising organizational machinery which will facilitate the contribution of all governmental levels to the common endeavor.

Although it is clear that a local agency, such as the MWCD, cannot, and should not, operate independently, there is evidence that it can contribute significantly, and perhaps more effectively than the MWCD is now able to do, to the comprehensive development of its basin.

Much of the deterioration in the MWCD's leadership came as a result of two forces: ( $x$ ) the District's withdrawal from its cost-sharing commitment, and (2) the disregard by federal policies and programs of state and local participation. Although the MWCD was forced to renege on the major part of its cost-sharing obligation, this was owing to forces which may not be operative, or at least not as compelling, today. Without doubt, the depression was a major factor in the MWCD's withdrawal from its cost-sharing contract. Not only was the financial capacity of the local units of government progressively declining, but as a concomitant, the progressive liberalization of policy regarding federal financing of drainage development projects melted the local spine. At the same time, explosive expansions of federal programs relating to land and water development gave little consideration to the possible contributions which local units of government-much less local watershed agencies-could render.

Today, three factors tend to mitigate the negative influences which the MWCD experienced in its efforts to maintain a significant role in the development program. 
Now, instead of depression, the economy is enjoying a vitality undreamed of in predepression days. Circumstances are now much more favorable for local authorities to levy taxes and benefit assessments appropriate to local sharing in drainage basin development. Secondly, federal and state agencies are now seeking a modus vivendi among each other and with local units. In the two-and-a-half decades since the early New Deal expansions, many different methods of intergovernmental relations have been tested. Both desire and knowledge with respect to local participation in land and water management are greater today. Lastly, the problems of land and water management are becoming more pressing, and the potentialities of rational comprehensive development are becoming more evident. As localities begin to face up to the limits of their areas in terms of water and land-water relationships, the environment is further favorably conditioned for effective local participation in drainage basin development.

If these assumptions are accepted, the question may then be posed: "What are the essential elements to effective participation by a small drainage basin agency in a development program for its basin?" The MWCD's experience suggests three important functions which such an agency may perform.

Fundamental to a comprehensive basin development program is local support. Here, the local drainage basin agency can make a primary contribution in providing leadership. Such support can only result from comprehensive public education of the watershed community with respect to the interrelated character of the land and water problems, potentialities, and courses of action. In turn, a public education program, if it is to be respected and sustained, must be built upon continuing surveys and research into basin-wide problems and possibilities. Here, then, the local agency's contribution is the holistic view. Rather than confining its efforts to conducting technical surveys, more appropriately the function of existing governmental or private agencies, the local agency should relate such piecemeal technical studies to the total drainage-basin problem. If such basin-wide studies support an active program of public education and particiaption, the local agency can perform effectively as leader and spokesman for the valley community.

Closely related to leadership is the function of unofficially coordinating the activities within the basin which may affect land and water development. Effectiveness in this role is dependent not only on the local agency's leadership status, but upon the possession of a tangible and dynamic plan of development. Such a plan must be under constant evolution based upon close consultation with private and public agencies concerned. In many respects, such a plan is the technical and political expression of the result of the agency's basin-wide surveys. And just as the plan will strengthen the local agency as a leader in the watershed community, it will also strengthen its coordinating influence among federal and state agencies working in the basin.

Finally, if a local drainage-basin agency is to participate effectively in the development program in its basin, it must serve as the vehicle for local cost-sharing. It 
can, if established as a corporate subdivision of the state, as are the Ohio conservancy districts, possess the power of state and local assessment to capture benefit payments which otherwise may legally be difficult to collect. A greater return from direct local beneficiaries is sound policy for the future. It reduces the ultimate load on the general taxpayer, it encourages greater local responsibility, and, because of a fairer distribution of costs, it provides a more favorable basis for federal participation in drainage basin development.

Whatever the future direction of federal, state, and interstate cooperation in drainage basin development, a local agency based upon a watershed jurisdiction and prepared to perform in these general areas has a vital place in sound drainage basin development. 